\section{Irrigation Regimes Affect Leaf Yield and Water Use by Turnip and Mustard}

\author{
Doyle A. Smittle', W. Lamar Dickens ${ }^{1}$, James R. Stansell', \\ and Eric Simonne ${ }^{1}$ \\ University of Georgia, Coastal Plain Experiment Station, Tifton, \\ GA 31793
}

Additional index words. Brassica rapa, B. juncea, soil water tension, evapotranspiration, evaporation, irrigation scheduling, water-use modeling

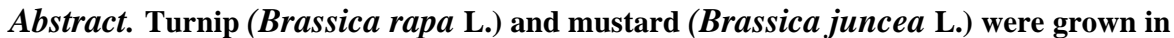
drainage lysimeters under controlled soil water regimes during 2 years. Irrigation regimes consisted of water applications when the soil water tension at a $10-\mathrm{cm}$ depth exceeded 25,50, or $75 \mathrm{kPa}$ throughout growth of the two crops on two soil types during spring and fall production seasons. Leaf yield and water use were highest when irrigation was applied at $25 \mathrm{kPa}$ soil water tension. Regression equations are presented to describe the relationships of daily pan evaporation and water use to plant age, and to compute daily evapotranspiration : pan evaporation ratios (crop factors) during spring and fall production seasons.
\end{abstract}

Turnip and mustard greens grow rapidly, and irrigation must be applied to ensure the active foliage growth required for good yields of high-quality greens (Barber, 1983). Although short-term water deficits (Barber, 1983) or water excesses (Mullins and Swingle, 1975) may have substantial negative effects on the yield of greens, there are very few reports of irrigation research for either turnip or mustard.

Leaf yields were increased $\mathbf{5 2 \%}$ to $\mathbf{1 3 9 \%}$ when turnips were irrigated at wilting, as compared to turnips grown without irrigation (del Vane et al., 1965). Substantial yield reductions of many drought-sensitive vegetables can occur before water stress becomes severe enough to cause wilting (Bruce et al., 1980; Smittle et al., 1990; Stansell and Smittle, 1980). Therefore, we would expect yield increases from an optimum irrigation regime to be greater than those reported by del Vane et al. (1965).

Irrigation has also increased turnip root yields (Lal and De, 1972) and mustard seed yields (Joarder et al., 1979; Prihar et al., 1981); however, foliage growth has generally been more sensitive to water stress than storage root growth or seed yield (Bruce et al., 1980).

The leaf yield responses of turnip and mustard to water stress less severe than that required to induce wilting have not been reported, although Lal and De (1972) found

\footnotetext{
Received for publication 5 Apr. 1991. Accepted for publication 9 Oct. 1991. Supported by state and Hatch Act funds allocated to the Georgia Agricultural Experiment Stations and the Richard King Mellon Foundation. The cost of publishing this paper was defrayed in part by the payment of page charges. Under postal regulations, this paper therefore must be hereby marked advertisement solely to indicate this fact.

'Dept. of Horticulture.

${ }^{2}$ Dept. of Agricultural Engineering.
} sand soils. season. matic rainfall shelters activated by rainfall (Stansell and Smittle, 1980). Each shelter contained 12 plots each of turnip and mustard during spring and fall production seasons. A combination of between-plot moisture barriers (1.2 m deep) and subsurface drains was used to isolate the plots from each other and from groundwater intrusion. Each shelter protected twenty-four $1.5 \times 1.8$-m plots of a single soil type. Each plot contained six resistance blocks soil moisture sensors placed at depths of 10, 23, 38, 53, 81, and $107 \mathrm{~cm}$. The sensors were read daily beginning at 0800 HR by a data collection system controlled by an on-site computer. The data were processed by the computer, and a daily report was printed that included the soil water content at each sensor depth and the irrigation requirements for the day. Soil water data were stored for future analyses.

Irrigation treatments within the eight cropseason-soil type combinations were arranged in a randomized complete-block design with four replications. Treatments consisted of irrigating at soil water tensions of 25,50 , or $75 \mathrm{kPa}$. For 10 days after seeding, water was applied by hand as needed. Irrigations during the 11- to 64-day growth period were scheduled by measured soil water deficits. When sensors at the $10-\mathrm{cm}$ depth showed soil water tension corresponding to the treatment requirements, water was applied to refill the surface $30 \mathrm{~cm}$ of the soil profile to field capacity $(8 \mathrm{kPa})$. The amount of water applied represented the average of the four replications and was determined from water retention curves for each soil (Stansell and Smittle, 1980).

Climatological data, including rainfall, open pan evaporation, wind movement, relative humidity, and maximum and minimum air temperatures were collected daily at the research site.

Plots were hand-tilled to incorporate fer-

Table 1. Effect of irrigation regimes on yield and water use of 'Shogoin' turnip and 'Southern Giant Curled' mustard grown during spring and fall production seasons on Tifton loamy sand and Bonifay

\begin{tabular}{|c|c|c|c|c|}
\hline \multirow[b]{2}{*}{ Crop-season-soil } & \multicolumn{3}{|c|}{ Irrigation regime $(\mathrm{kPa})$} & \multirow[b]{2}{*}{ Significance $^{y}$} \\
\hline & 25 & 50 & 75 & \\
\hline \multicolumn{5}{|c|}{ Leaf yield $\left(t \cdot h a^{-1}\right)$} \\
\hline Turnip-spring-Tifton & 31.7 & 28.2 & 28.4 & NS \\
\hline Turnip-spring-Bonifay & 28.2 & 24.0 & 21.0 & $\mathrm{~L}^{* *}, \mathrm{Q}^{*}$ \\
\hline Turnip-fall-Tifton & 50.3 & 42.9 & 44.5 & $\mathrm{Q}^{*}$ \\
\hline Turnip-fall-Bonifay & 44.9 & 43.2 & 40.9 & $\mathrm{O}^{*}$ \\
\hline Mustard-spring-Tifton & 24.0 & 20.7 & 21.3 & $Q^{*}$ \\
\hline Mustard-spring-Bonifay & 18.1 & 15.7 & 14.9 & $\mathrm{Q}^{*}$ \\
\hline Mustard-fall-Tifton & 42.2 & 36.1 & 29.1 & $\mathrm{~L}^{* *}$ \\
\hline Mustard-fall-Bonifay & 37.4 & 33.9 & 33.4 & $\mathrm{Q}^{*}$ \\
\hline \multicolumn{5}{|c|}{ Water use $(\mathrm{mm})$} \\
\hline Turnip-spring-Tifton & 107 & 97 & 87 & \\
\hline Turnip-spring-Bonifay & 114 & 109 & 96 & \\
\hline Turnip-fall-Tifton & 127 & 129 & 124 & \\
\hline Turnip-fall-Bonifay & 163 & 139 & 135 & \\
\hline Mustard-spring-Tifton & 101 & 87 & 83 & \\
\hline Mustard-spring-Bonifay & 92 & 97 & 81 & \\
\hline Mustard-fall-Tifton & 114 & 97 & 97 & \\
\hline Mustard-fall-Bonifav & 131 & 109 & 102 & \\
\hline
\end{tabular}

${ }^{2}$ Plots were harvested twice during the 64-day spring season and three times during the 65-day fall

'Linear (L) and quadratic (Q) effects of irrigation regimes.

NS,***Nonsignificant or significant at $P=0.05$ or 0.01 , respectively. 


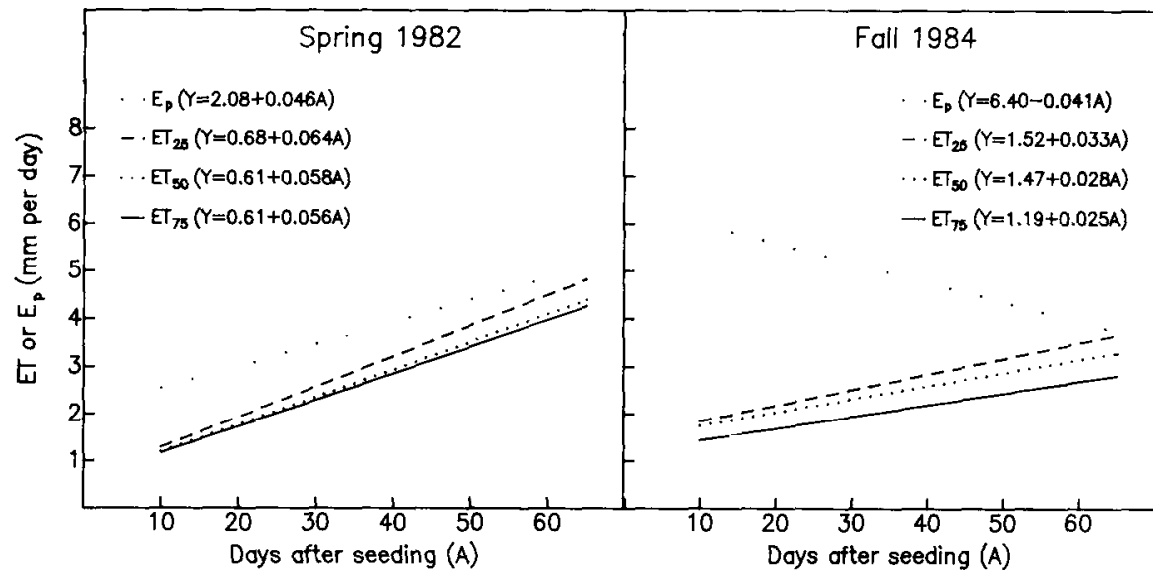

Fig. 1. Change in daily pan evaporation ( $\mathrm{E}_{\mathrm{p}}$ and evapotranspiration (ET) of greens (turnip and mustard) irrigated at 25,50 , and $75 \mathrm{kPa}$ during spring and fall production seasons.

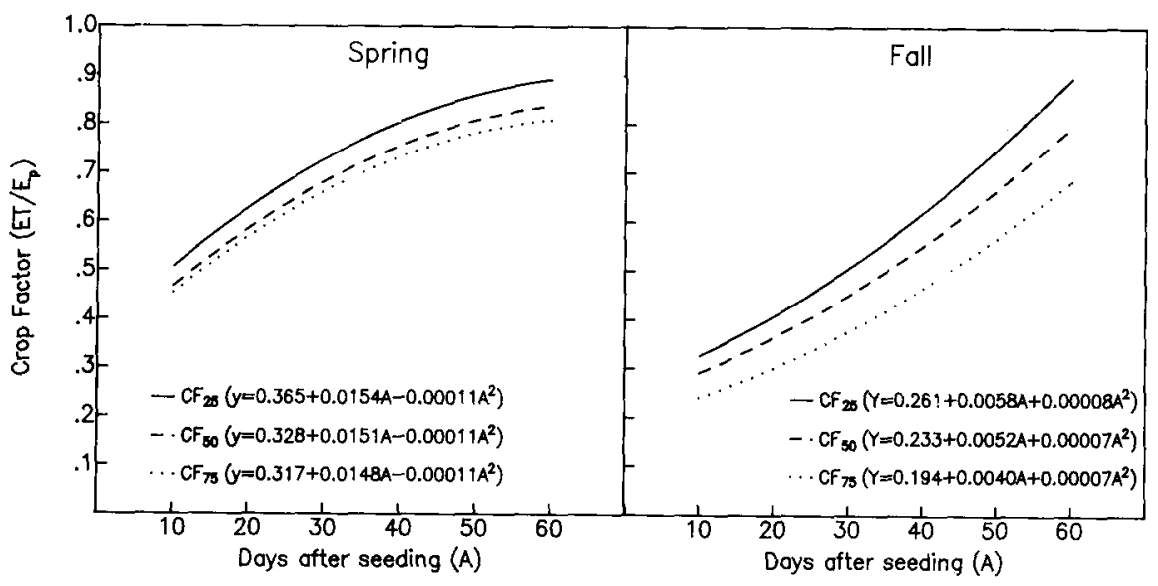

Fig. 2. Change in daily crop factors for greens (turnip and mustard) irrigated at 25, 50, and $75 \mathrm{kPa}$ during spring and fall production seasons.

tilizers applied at the ratesof45N40P-112K (kg-ha-'). Seeds were planted by hand on 10 Feb. 1982 for spring and 21 Aug. 1984 for fall production. The seeds were planted in four rows spaced $30 \mathrm{~cm}$ apart. Each row consisted of two lines spaced $5 \mathrm{~cm}$ apart with plants spaced $1 \mathrm{~cm}$ apart in each line. Broadcast nitrogen applications at the rate of 34 $\mathrm{kg} \mathrm{N} / \mathrm{ha}$ were made 3 weeks after seeding and after each harvest.

On 25 Mar. and 15 Apr. 1982 and 20 Sept., 9 Oct., and 25 Oct. 1984, leaves were cut 3 to $4 \mathrm{~cm}$ above the soil and weighed. Samples of the leaves were taken from each plot of the 25 Mar. 1982 harvest for quality analyses of blade : stem ratio, color, chlorophyll, and dry weight. Midribs and stems were removed from $200 \mathrm{~g}$ of leaves, and both petioles and blade portions were weighed, dried, and reweighed. Another 100-g sample was blended with an equal weight of water for 3 rein, and the resulting slurry was used for chlorophyll, dry weight, and color determination as described by Smittle (1986).

Yield and quality data for irrigation regimes were subjected to regression analyses, wherein the eight crop-season-soil type combinations were considered as separate experiments. The relationships between water use and pan evaporation during the spring and fall production season were established spectively. Wilting of the foliage was observed only in the $75-\mathrm{kPa}$ irrigation regime when evaporative demand was high. The 75$\mathrm{kPa}$ irrigation regime represents a water stress level similar to that of the irrigated treatment of earlier research (del Vane et al., 1965). The lower leaf yields with irrigation at soil water tensions of $50 \mathrm{kPa}$ as compared to irrigation at $25 \mathrm{kPa}$ confirm the statement of Lal and De (1972) that plant growth decreases long before the soil moisture reaches the wilting point.

Leaf quality characteristics, petiole: blade ratio, chlorophyll content, percent dry weight, and leaf color were not affected by irrigation regimes (data not presented).

Water use was not determined during the first 10 days after seeding, but sufficient water $(\approx 25 \mathrm{~mm})$ was applied to ensure that the soil was at field capacity upon initiation of sensor-controlled irrigation scheduling. Water use rates ranging from 81 to $163 \mathrm{~mm}$ reflect water applications during the period when irrigations were scheduled from soil water measurements (Table 1). During this period, an average of nine, seven, and six irrigations were required for the 25,50 , and $75 \mathrm{kPa}$ irrigation regimes, respectively. Although the amount of water applied at each irrigation decreased as the soil water tension at the time of irrigation decreased, total water applied was highest when irrigation was applied at $25 \mathrm{kPa}$. These results follow the general trend that crops that receive more frequent irrigations have higher use and often higher yields under given climatic conditions (Bruce et al., 1980; Stansell and Smittle, 1980; Stegman et al., 1980). Correlation analyses showed a highly significant positive relationship $(r=0.81)$ between water use and leaf yields in this study.

Water applied is a valid estimate of water use or evapotranspiration, since these plots were protected from rainfall and ground water intrusions and water additions were based on water content in the soil profile. Cumulative pan evaporation $\left(E_{p c}\right)$ and cumulative evapotranspiration $\left(\mathrm{ET}_{\mathrm{c}}\right)$ for each crop-seasonsoil type combination with irrigation at 25 , 50 , and $75 \mathrm{kPa}$ were compiled. The relationships (data for crops and soil types combined) of $\mathrm{E}_{\mathrm{pc}}$ and $\mathrm{ET}_{\mathrm{c}}$ to plant age (days from seeding) for the spring season accounted for $99.9 \%$ of the variation of $\mathrm{E}_{\mathrm{pc}}$ and $97.9 \%$, $98.1 \%$, and $98.3 \%$ of the variations of $\mathrm{ET}_{=}$ for irrigation regimes of 25,50 , and $75 \mathrm{kPa}$, respectively. For the fall season, the equations accounted for $99.9 \%$ of the variation of $E_{p c}$ and $95.5 \%, 96 . \%$, and $95.9 \%$ of the variations of $\mathrm{ET}_{\mathrm{C}}$ for irrigation regimes of 25,50 , and $75 \mathrm{kPa}$, respectively. Cubic responses for $\mathrm{E}_{\mathrm{pc}}$ and $\mathrm{ET}_{\mathrm{c}}$ were not statistically significant for either the spring or fall season; therefore, daily pan evaporation $\left(\mathrm{E}_{\mathrm{p}}\right)$ and daily evapotranspiration (ET) equations, computed as the derivative of the $\mathrm{E}_{\mathrm{pc}}$ and $\mathrm{ET}_{\mathrm{C}}$ equations, are linear.

Both $E_{p}$ and ET increased with plant age during the spring season, but $\mathrm{E}_{\mathrm{p}}$ decreased and ET increased with age during the fall season (Fig. 1). These results suggest that scheduling irrigations as a constant percent- 
age of $E_{p}$, as suggested by Singh (1989), or a constant crop factor, as suggested by Jensen and Middleton (1970), would result in a much larger error for the fall season than for the spring season. The data also show that a single crop factor when multiplied by $\mathrm{E}_{\mathrm{p}}$ would not accurately estimate ET in. water balance models as outlined by Stegman et al. (1980).

Daily crop factors $(\mathrm{CF})$, expressed as $\mathrm{CF}$ $=\mathrm{ET} / \mathrm{E}_{\mathrm{p}}$, were computed for days 10 through 65 for each irrigation regime during the spring and fall seasons (Fig. 2). Change in CF with age was quadratic during both growing seasons. During spring, CF showed a rapid initial increase then a slower rate of increase as plants aged. However, during the fall, CF increased slowly when plants were young then increased more rapidly as the production season progressed. This difference in the change of $\mathrm{CF}$ with age during the spring and fall seasons may have been due to reduced relative growth rates of turnip and mustard during the spring when average daily temperatures are above 25C (Lorenz and Maynard, 1980). Crop factors were higher when irrigations were applied at lower soil water tensions. These results are in agreement with earlier reports (Bruce et al., 1980; Singh, 1989; Stansell and Smittle, 1980; Stegman et al., 1980) that state the rate of water use is increased by more frequent irrigations. The daily $\mathrm{CF}$ developed from the regression equations of Fig. 2, when multiplied by measured pan evaporation data, provides an accurate estimation of ET for use in waterbalance irrigation models (Smittle et al., 1990; Stegman et al., 1980). For example, in water balance equations where $\mathrm{ET}=\mathrm{E}_{\mathrm{p}}(\mathrm{CF})$, if $\mathrm{E}_{\mathrm{p}}$ were $5 \mathrm{~mm}$ on days 20 and 60 after seeding turnip, ET would be $3.2 \mathrm{~mm}(5 \times 0.63)$ on day 20 and $4.5 \mathrm{~mm}(5 \times 0.89)$ on day 60.

We have shown that leaf yields of turnip and mustard were highest with irrigation applications when the soil water tension at 10 $\mathrm{cm}$ exceeded $25 \mathrm{kPa}$. This irrigation regime also required more water than irrigation applications at soil water tensions of 50 and 75 $\mathrm{kPa}$. Regression equations were developed to compute daily water use and daily crop factors for growth during the spring and fall production seasons. These equations provide a daily adjustment of $E_{p}$ to estimate daily ET for turnip and mustard for use in water-balance irrigation scheduling models.

\section{Literature Cited}

Barber, J.M. 1983. Turnip green production. Georgia Ext. Ser. Hort. 3.

Bruce, R. R., J.L. Chesness, T.C. Keisling, J.E. Pallas, Jr., D.A. Smittle, J.R. Stansell, and A.W. Thomas. 1980. Irrigation of crops in the southeastern United States: Principles and practices. U.S. Dept. Agr. Sci. Educ. Administration Agr. Rev. and Man. ARM-S-9.

del Valle, C. G., S.A. Harmon, and R.E. Worley. 1965. Effects of fertilizer rates and moisture levels on turnip greens production. Georgia Agr. Res. 7(2):2-5.

Jensen, M.E. and J.E. Middleton. 1970. Scheduling irrigation from pan evaporation. Washington Agr. Expt. Sta. Circ. 527.
Joarder, O.I., N.K. Paul, and S.K. Ghose. 1979. Effects of irrigation and fertilizer on mustard (Brassica juncea). Expt. Agr. 15:299-302.

Lal, B. and R. De. 1972. Fertilizer and moisture requirements of turnip (Brassica rapa $\mathrm{L}$.). Indian J. Agr. Sci. 42(2):156-160.

Lorenz, O.A. and D.N. Maynard. 1980. Knott's handbook for vegetable growers. 2nd ed. Wiley, New York.

Mullins, C.A. and H.D. Swingle. 1975. Collard, kale, mustard, and turnip greens varieties for the Cumberland plateau. Tennessee Farm Home Sci. Prog. Rpt. 93:32-33.

Prihar, S. S., K.S. Sandhu, K.L. Khera, and B.S. Sandhu. 1981. Effects of irrigation schedules on yield of mustard (Brassica juncea). Expt. Agr. 17:105-111.

SAS Institute. 1982. SAS user's guide: Statistics,
1982 ed. SAS Inst., Cary, N.C.

Singh, B.P. 1989. Irrigation management for bush snapbean production. HortScience 24:69-70.

Smittle, D.A. 1986. Influence of cultivar and temperature on lima bean yield and quality. J. Amer. Soc. Hort. Sci. 111:655-659.

Smittle, D. A., W.L. Dickens, and J.R. Stansell 1990. An irrigation scheduling model for snap beans. J. Amer. Soc. Hort. Sci. 115:226-230.

Stansell, J.R. and D.A. Smittle. 1980. Effects of irrigation regimes on yield and water use of snap beans (Phaseolus vulgaris L.). J. Amer. Soc. Hort. Sci. 105:869-873.

Stegman, E. C., J.R. Musick, and J.I. Stewart. 1980. Irrigation water management, p. 763-816. In: M.E. Jensen (cd.). Design and operation of farm irrigation systems. Amer. Soc. Agr. Eng., St. Joseph, Mich. 